\title{
Efektivitas Komunikasi Antarpribadi Petani Dalam Budidaya Padi Organik Di Desa Gentungan Kecamatan Mojogedang Kabupaten Karanganyar
}

\author{
The Effectiveness Of Farmers Interpersonal Communication In Organic Rice Culture In \\ Gentungan Village, Mojogedang Subdistrict, Karanganyar Regency \\ Wijang Prasetiyo Aji, Suminah, Hanifah Ihsaniyati
}

Program Studi Penyuluhan dan Komunikasi Pertanian Fakultas Pertanian

Universitas Sebelas Maret

J1.Ir.Sutami No.36 A Kentingan Surakarta 57126 Telp./Fax (0271) 637457

Email : wijangprasetiyoaji@gmail.com

\begin{abstract}
This study aims to assess the factors that influence farmers' interpersonal communication in organic rice cultivation; assess the level of effectiveness of farmer interpersonal communication in organic rice cultivation; and analyze the influence of openness, empathy, attitudes and equality partially and simultaneously on the level of effectiveness of interpersonal communication of farmers in organic rice cultivation. The research location in Gentungan village, Mojogedang Subdistrict, Karanganyar Regency, with the consideration that Mojogedang Subdistrict has the highest organic rice production in Karanganyar Regency and Gentungan Village is the only village that has an organic rice certificate. This research was conducted using quantitative deskriptive method with census technique for all organic rice farmers who were certified with a total of 45 people. The data analysis used in this study is multiple linear regression. The results of the study indicate that; openness is included in the category of being quite open, empathy is included in the medium category, attitudes are included in the good category, and equality in the medium category; the level of effectiveness of interpersonal communication of farmers in organic rice cultivation is included in the high category; factors that influence interpersonal communication (openness, empathy, attitude and equality) simultaneously have a significant effect on the level of effectiveness of interpersonal communication while partially openness $\left(X_{2}\right)$, attitude $\left(X_{3}\right)$ and equality $\left(X_{4}\right)$ significantly influence the level of effectiveness interpersonal communication while empathy $\left(X_{2}\right)$ does not significantly influence the $95 \%$ confidence level.
\end{abstract}

Keywords: Effectiveness of Communication,Interpersonal Communication, Organic Rice.

Abstrak: Penelitian ini bertujuan untuk mengkaji faktor-faktor yang mempengaruhi komunikasi antarpribadi petani dalam budidaya padi organik; mengkaji tingkat efektivitas komunikasi antarpribadi petani dalam budidaya padi organik; dan mennganalisis pengaruh keterbukaan, empati, sikap dan kesetaraan secara parsial dan simultan terkadap tingkat efektivitas komunikasi antarpribadi petani dalam budidaya padi organik. Lokasi penelitian di Desa Gentungan Kecamatan Mojogedang Kabupaten Karanganyar dengan pertimbangan bahwa Kecamatan Mojogedang memiliki produksi padi organik tertinggi di Kabupaten Karanganyar dan Desa Gentungan merupakan satu-satunya desa yang memiliki sertifikat beras organik. Penelitian ini dilakukan dengan metode desktiptif kuantitatif dengan teknik sensus kepada seluruh petani padi organik yang tersertifikasi dengan jumlah 45 orang. Analisis data yang digunakan dalam penelitian ini adalah regresi linier berganda. Hasil penelitian menunjukkan bahwa;keterbukaan termasuk dalam kategori cukup terbuka, empati termasuk dalam kategori sedang, sikap termasuk dalam kategori baik, dan kesetaraan dalam kategori sedang; tingkat efektivitas komunikasi antarpribadi petani dalam budidaya padi organik termasuk dalam kategori tinggi; faktor-faktor yang mempengaruhi komunikasi antar pribadi(keterbukaan, empati, sikap dan kesetaraan) secara serentak berpengaruh secara signifikan terhadap tingkat efektivitas komunikasi antarpribadi sedangkan secara parsial keterbukaan $\left(\mathrm{X}_{1}\right)$, sikap $\left(\mathrm{X}_{3}\right)$ dan kesetaraan $\left(\mathrm{X}_{4}\right)$ secara signifikan berpengaruh terhadap tingkat efektivitas komunikasi antar pribadi sedangkan empati $\left(\mathrm{X}_{2}\right)$ tidak berpengaruh secara signifikan pada taraf kepercayaan $95 \%$.

Kata Kunci: Efektivitas Komunikasi,Komunikasi Antarpribadi, Padi Organik. 


\section{PENDAHULUAN}

Kesadaran masyarakat akan pentingnya mengkonsumsi produk pangan organik mulai berkembang di masa sekarang ini. Hal ini dilakukan sebagai penanggulangan akan bahaya yang ditimbulkan oleh penggunaan bahan kimia dalam kegiatan produksi pertanian. Produk organik aman dikonsumsi karena bebas dari residu dan zat berbahaya (Andoko,2010). Pemerintah telah melakukan upaya berupa inovasi-inovasi baru terkait pertanian organik salah satunya adalah program padi organik. padi organik merupakan padi yang disahkan oleh sebuah badan independen, untuk ditanam dan diolah menurut standar organik yang ditetapkan(Litbang 2007).

Komunikasi menjadi penting dalam penyebaran informasi terkait program padi organik.Soekartawi (1998) menyatakan bahwa keberhasilan proses adopsi inovasi dalam alih teknologi tidak terlepas dari arus informasi yang diterima oleh petani melalui komunikasi. Komunikasi yang terjadi bisa menjadi efektif ataupun tidak efektif. Komunikasi yang efektif akan meningkatkan pengetahuan tentang informasi yang disampaikan sehingga terjadi kesamaan makna antara komunikator dan komunikan, serta sebagai hasil dari proses tersebut akan membentuk keinginan untuk melaksanakan informasi ang disampaikan. Komunikasi terbagi menjadi dua jenis yaitu intrapersonal (dengan diri sendiri) dan interpersonal (dengan orang lain). Komunikasi antarpribadi diartikan sebagai proses pengiriman dan penerimaan pesan-pesan antara dua orang, atau diantara sekelompok kecil orang-orang, dengan beberapa efek dan beberapa umpan balik seketika (Devito 1997).

Kecamatan Mojogedang merupakan daerah penghasil beras organik tertinggi di Kabupaten Karanganyar. Berdasarkan data Dinas Pertanian (2016), jumlah produksi beras organik Kecamatan Mojogedang sebesar 3.225 Ton. Pelaksanaan program padi organik pada tahun 2016/2017 hanya berada di Desa Gentungan. Pelaksanaan program di lokasi tersebut dapat dikatakan berhasil dibuktikan dengan sertifikat beras organik No. 098-LSPO_005-IDN-10-14 yang diterbitkan oleh LESOS. Peneliti ingin mengkaji tingkat efektivitas komunikasi antarpribadi petani di lokasi yang sudah berhasil tersebut. Hal tersebut diduga dipengaruhi beberapa faktor yaitu keterbukaan, empati, sikap dan kesetaraan. Penelitian ini bertujuan untukmengkaji karakteristik komunikasi antarpribadi petani dalam budidaya padi organik di Desa Gentungan Kecamatan Mojogedang Kabupaten Karanganyar, mengkaji tingkat efektifitas komunikasi antar pribadi petani dalam budidaya Padi Organik di Desa Gentungan Kecamatan Mojogedang Kabupaten Karanganyar dan mengkaji pengaruh factor-faktor yang mempengaruhi komunikasi antarpribadi terhadap tingkat Efektivitas komunikasi antar pribadi petani dalam budidaya Padi Organik di Desa Gentungan Kecamatan Mojogedang Kabupaten Karanganyar secara parsial dan simultan.

\section{METODE PENELITIAN}

Penelitian ini menggunakan metode penelitian kuantitatif dengan teknik survey. Pemilihan lokasi dilakukan secara sengaja atau purposive di Desa Gentungan Kecamatan Mojogedang dengan pertimbangan bahwa daerah tersebut memiliki produksi padi organik tertinggi di Kabupaten Karanganyar dan Desa Gentungan merupakan satu-satunya desa yang memiliki setifikat beras organik. Populasi dalam penelitian adalah seluruh petani di Kelompok Tani Tani Mulyo 1 yang telah memiliki sertifikat beras organik dengan jumlah 45 petani. Penelitian ini dilakukan secara sensus kepada seluruh populasi penelitian.. Jenis data yang digunakan dalam penelitian ini adalah data primer dan sekunder. Teknik pengumpulan data dilakukan dengan Observasi, wawancara dan pencatatan.

Metode analisis data yang digunakan dalam penelitian ini adalah regresi berganda. Selain itu, dilakukan beberapa uji lainnya yakni, uji validitas dengan pengambilan sampel sebanyak 20 responden dengan nilai $r$ tabel sebesar 0,444, kemudian dilakukan uji reliabilitas yang diukur dengan ketentuan nilai cronbach alpha $>0,60$. Hasil dari uji reliabilitas pada penelitian ini sebesar 0,985 lebih dari 0,60 yang berarti data penelitian dinyatakan reliabel. Sebelum dilakukannya analisis regresi, dilakukan uji asumsi klasik terlebih dahulu, yakni uji normalitas, uji heterokedastisitas dan uji multikolinearitas. Hasil uji asumsi klasik dari penelitian ini menujukkan bahwa penelitian ini 
sudah memenuhi syarat untuk kemudian dianalisis dalam analisis pengaruh menggunakan regresi. Uji kesesuaian dalam analisis regresi berganda menggunakan uji koefisien determinasi $\left(\mathrm{R}^{2}\right)$ bertujuan untuk menjelaskan kemampuan model dalam menerangkan variasi variabel dependen. Uji $F$ bertujuan untuk mengetahui pengaruh variabel independen terhadap variabel dependen secara simultan, sedangkan uji t untuk melihat pengaruh secara parsial.

\section{HASIL DAN PEMBAHASAN}

Budidaya padi organik di Desa Gentungan merupakan bukti dari pelaksanaan program padi organik yang dikeluarkan oleh menteri pertanian yakni Permenpan 64 Tahun 2013. Kegiatan budidaya organik di lokasi tersebut bisa dikatakan sudah berhasil dengan dimilikinya sertifikat beras organik No. 098-LSPO 005-IDN-10-14 yang diterbitkan oleh LeSOS $^{-}$(Lembaga Sertifikasi Organik Seloliman). Area lahan untuk budidaya padi organik seluas 7,2 Ha yang terbagi dalam 45 petak lahan petani

Kegiatan budidaya padi organik meliputi pengolahan lahan, pengairan, pembenihan, pemupukan, pengendalian organisme pengganggu tanaman (OPT). Sertifikasi beras organik dijadikan sebagai bukti bahwa produk organik di Desa Gentungan telah dikaji oleh lembaga sertifikasi organik dan memenuhi persyaratan. Kegiatan sertifikasi padi organik di dampingi stake holder seperti peran pemerintah melalui dinas pertanian, penyuluh pertanian lapang maupun di tingkat desa. pendampingan yang dilakukan secara berkala atau rutin guna memberikan arahan untuk meningkatkan pengetahuan petani terkait budidaya padi organik.

\section{Faktor-faktor yang Mempengaruhi Efektivitas Komunikasi Antarpribadi}

Menurut Devito (1997 ), Komunikasi antar pribadi diartikan sebagai proses pengiriman dan penerimaan pesan - pesan antara dua orang, atau diantara sekelompok kecil orang - orang, dengan beberapa efek dan beberapa umpan balik seketika. komunikasi antarpribadi, seperti bentuk perilaku yang lain, dapat sangat efektif dan dapat pula sangat tidak efektif. Karakteristik komunikasi antarpribadi yang efektif menekankan pada keterbukaan, empati, sikap dan kesetaraan. Berikut ini disajikan tabel faktor-faktor yang mempengaruhi efektivitas komunikasi antarpribadi petani berdasarkan analisis frekuensi responden

Tabel 1. Distribusi Faktor-faktor yang Mempengaruhi Efektivitas Komunikasi Antarpribadi Petani dalam Budidaya Padi Organik di Desa Gentungan Kecamatan Mojogedang Kabupaten Karanganyar.

\begin{tabular}{lllrrr}
\hline \multirow{2}{*}{ No } & Variabel & Kategori & Skor & & \multicolumn{2}{c}{ Distribusi } \\
\cline { 5 - 6 } & & Cukup terbuka & $39,1-51,1$ & & $\mathbf{N}$ \\
\hline 1 & Keterbukaan & Sedang & $39,1-51,1$ & 25 & 46,7 \\
2 & Empati & Baik & $54,5-67,2$ & 20 & 44,6 \\
3 & Sikap & Sedang & $18,3-23,8$ & 23 & 51,1 \\
4 & Kesetaraan & &
\end{tabular}

Berdasarkan Tabel 1,diketahui bahwa keterbukaan petani dalam budidaya padi organik sebagian besar pada kategori cukup terbuka sebanyak 21 orang dengan prosentase sebesar 46,7\%.Hal ini dikarenakan petani kebanyakan memberikan dan menerima informasi terkait pengolahan lahan, pembenihan, pengairan dan pemupukan akan tetapi petani jarang berkomunikasi terkait pengendalian OPT. Petani dalam pengendalian OPT sudah merasa mampu untuk mandiri sehingga kegiatan dilakukan secara sendiri-sendiri tanpa memerlukaninformasi dari petani lain. Komunikasi dikatakan berhasil jika komunikasi tersebut tidak sebatas dalam penyampaian pesan tetapi juga harus bersifat terbuka, komunikasi yang demikian ini bisa menghapus pasangka buruk atau kecurigaan yang mungkin terjadi dalam membangun rasa saling pengertian antara pihak satu dengan yang lainnya sehingga pesan yang disampaikan dapat dipahami, difikirkan dan akhirnya dilaksanakan (Ruslan, 1988). 
Empati ditinjau dari kemauan petani untuk mendengarkan apa yang dikatakan oleh petani lain. Selanjutnya penerima pesan akan mengetahui dan merasakan apa yang dikatakan oleh pengirim pesan sehingga akan timbul perasaan atau keinginan untuk bertindak atau membantu menyelesaikan masalah. Empati petani sebagian besar dalam kategori sedang sebanyak 25 orang dengan prosentase $55,6 \%$. Hal ini dikarenakan petani sering berkomunikasi terkait pengairan dan pemupukan organik akan tetapi untuk pengolahan lahan, pembenihan dan pengendalian OPT komunikasi hanya dilakukan kadang-kadang. Hanya sebagian kecil petani yang menceritakan keluh kesahnya kepada petani lain dalam bahasan pengolahan lahan, pembenihan dan pengendalian OPT dikarenakan petani merasa memiliki pemahaman yang sudah baik sehingga mampu mengorganisir sendiri seluruh kegiatan budidaya tanpa campur tangan petani lain.

Sikap menurut Azwar (1998) merupakan suatu predisposisi yang dipelajari utuk merespon secara konsisten dalam cara tertentu berkenaan denga obyek tertentu. Sikap petani ditinjau dari komponen kognitif (pemahaman), afektif (perasaan) dan konatif (kecenderungan bertindak). Sikap petani terhadap budidaya padi organik sebagian besar termasuk dalam kategori baik dengan jumlah 20 atau $44,4 \%$ dari total responden. Hal ini dikarenakan pemikiran petani dan perasaan petani mendukung budidaya padi organik sehingga mereka dengan senang hati mengadopsi di lahan pertaniannya. Jika dilihat dari kemampuan petani sendiri, rata-rata petani telah mengikuti serangkaian sosisalisasi, pelatihan maupun studi banding sejak tahun 2010 hingga sekarang ini sehingga pengalamannya akan terus diasah semakin baik lagi. Petani di lokasi penelitian sangat mendukung adanya program padi organik di wilayahnya.

Kesetaraan menurut Suranto (2011) berarti seseorang menempatkan diri setara dengan orang lain dan mengakui kepentingan yang berbeda dengan orang lain. Perasaan setara diwujudkan dengan perlakuan yang sama antara seseorang dengan orang lain dan tidak membedabedakan kepentingan salah satu pihak. Kesetaraan petani sebagian besar termasuk dalam kategori sedang dengan jumlah 23 orang atau 51,1\% dari total responden. Hal ini dikarenakan sebagian petani selalu menganggap hubungan antara petani satu dengan yang lain setara dan tidak membedabedakan antara satu orang dengan orang lainnya, namun kenyataannya juga terdapat sebagian lain yang mengakui adanya perbedaan sosial misalnya petani dengan lahan sempit akan merasa minder jika dibandingkan dengan petani berlahan luas dan adanya perasaan perlakuan yang berbeda dalam sosialisasi dan pelatihan antara petani anggota dan pengurus kelompok tani.

\section{Tingkat Efektivitas Komunikasi Antarpribadi}

Tingkat efektivitas komunikasi antarpribadipetani merupakan tingkat keberhasilan pesan yang dikirim oleh petani kepada petani lain dan ditindaklanjuti atau terdapat timbal balik dari pesan tersebut. semakin efektif suatu komunikasi yang dilakukan maka semakin tercapai tujuan dari komunikasi. Hardjana (2003) menyatakan bahwa Komunikasi antar pribadi dapat dikatakan efektif apabila pesan diterima dan dimengerti sebagaimana dimaksud oleh pengirim pesan, pesan ditindaklanjuti dengan sebuah perbuatan secara suka rela oleh penerima pesan dan dapat meningkatkan kulitas hubungan antarpribadi

Tabel 2. Distribusi Responden Berdasarkan Tingkat Efektivitas Komunkasi Antarpribadi Petani dalam Budidaya Padi Organik di Desa Gentungan Kecamatan Mojogedang Kabupaten Karanganyar.

\begin{tabular}{llclc}
\hline \multirow{2}{*}{ No } & Kategori & \multirow{2}{*}{ Skor } & & \multicolumn{2}{c}{ Distribusi } \\
\cline { 4 - 6 } & & & $\mathbf{N}$ & $\mathbf{\%}$ \\
\hline 1 & Sangat rendah & $20,0-36,0$ & 0 & 0,0 \\
2 & Rendah & $36,1-52,0$ & 10 & 22,2 \\
3 & Sedang & $52,1-68,0$ & 14 & 31,1 \\
$\mathbf{4}$ & Tinggi & $\mathbf{6 8 , 1 - 8 4 , 0}$ & $\mathbf{2 1}$ & $\mathbf{4 6 , 7}$ \\
5 & Sangat tinggi & $84,1-100,0$ & 0 & 0,0 \\
\hline
\end{tabular}


Data pada tabel 2 menunjukan bahwa tingkat efektivitas komunikasi antarpribadi petani sebagian besar termasuk dalam kategori tinggi dengan jumlah 21 orang atau $46,7 \%$ dari total responden. Hal ini dikarenakan komunikasi yang terjadi di lokasi penelitian sudah baik. Hal ini ditunjukkan dengan kesamaan makna yang dimiliki antar petani dalam budidaya padi organik sudah baik ditunjukkan dengan mudahnya petani untuk memahami informasi-informasi yang disampaikan oleh petani lain. Pesan yang didapatkan dari petani lain sebagian besar di lakukan serta terjadi peningkatan kualitas hubungan antarpribadi dilihat dari kebersamaan, keakraban yang terjadi dalam setiap kegiatan seperti perkumpulan rutin, kegiatan pengairan lahan dan pembuatan pupuk organik kelompok.

Pengaruh Keterbukaan $\left(\mathbf{X}_{1}\right)$, Empati $\left(\mathbf{X}_{2}\right)$, Sikap $\left(X_{3}\right)$ dan Kesetaraan $\left(X_{4}\right)$ terhadap Tingkat Efektivitas Komunikasi Antarpribadi Petani dalam Budidaya Padi Organik

Penelitian ini dilakukan untuk mengkaji pengaruh faktor-faktor yang mempengaruhi efekifitas komunikasi antarpribadi terhadap tingkat efekktivitas komunikasi antar pribadi. Berdasarkan analisis data diperoleh model persamaan regresi sebagai berikut:

$$
\begin{aligned}
\mathrm{Y}= & -1,551+0,417 \mathrm{X}_{1}+0,144 \mathrm{X}_{2}+0,371 \mathrm{X}_{3} \\
& +0,983 \mathrm{X}_{4}+\mathrm{e}
\end{aligned}
$$

Keterangan:

$\mathrm{Y}$ : tingkat efektivitas komunikasi antarpribadi,

$\mathrm{X}_{1}$ : keterbukaan, $\mathrm{X}_{2}$ : empati, $\mathrm{X}_{3}$ : sikap, $\mathrm{X}_{4}$ : kesetaraan dan e: faktor lain yang tidak diteliti

Tabel 3. Hasil Analisis Regresi
Berdasarkan hasil uji koefisien determinasi (R) diperoleh adjusted $R^{2}$ sebesar 0,816 . Artinya variabel independen (keterbukaan, empati, sikap dan kesetaraan) dapat menjelaskan variabel dependen (tingkat efektivitas komunikasi antarpribadi ) sebesar 81,6\% sedangkan sisanya sebesar $18,4 \%$ dijelaskan oleh faktor lain yang tidak diteliti. Devito (1997) mengemukakan bahwa selain dilihat dari ancangan humanistik, efektivitas komunikasi antar pribadi secara psikologis pragmatik meliputi confidence (sikap yakin), immediacy (kebersamaan), interaction management (manajemen interaksi), expressiveness (perilaku ekspresif) dan other orientation (orientasi pada orang lain).

Uji $F$ atau uji koefisien regresi secara serentak, pengujian ini digunakan untuk mengetahui pengaruh variabel independen secara serentak terhadap variabel dependen, apakah secara bersama-sama memiliki pengaruh yang signifikan atau tidak. Berdasarkan hasil analisisdiperoleh $\mathrm{F}$ sebesar 49,627 dengan $F$ tabel $(2,61)$ dengan tingkat signifikansi $(\alpha=0,05)$, dengan demikian Nilai $\mathrm{F}$ hitung $>F$ tabel atau 49,267>2,61. Berdasarkan perbandingan tersebut maka $\mathrm{H}_{0}$ ditolak dan $\mathrm{H}_{1}$ diterima, yang berarti variabel independen variabel keterbukaan $\left(X_{1}\right)$, empati $\left(X_{2}\right)$, sikap $\left(X_{3}\right)$ dan kesetaraan $\left(\mathrm{X}_{4}\right)$ berpengaruh signifikan secara bersama-sama terhadap variabel dependen tingkat efektivitas komunikasi antarpribadi(Y).

Uji $\mathrm{T}$ atau uji parsial digunakan untuk menguji signifikansi hubungan variabel-variabel independen (keterbukaan, empati, sikap dan kesetaraan); dengan variabel dependen tingkat efektivitas komunikasi antarpribadi. (Priyatno, 2012). Hasil uji parsial disajikan dalam tabel

\begin{tabular}{|c|c|c|c|c|}
\hline \multirow{2}{*}{ Variabel } & \multicolumn{2}{|c|}{ Unstandardized Coefficients } & \multirow{2}{*}{ Sig. } & \multirow{2}{*}{ Keterangan } \\
\hline & $\mathrm{B}$ & Std. Error & & \\
\hline (Constant) & -1.551 & 5.012 & .759 & \\
\hline Keterbukaan (X1) & .417 & .140 & .005 & Signifikan * \\
\hline Empati (X2) & .144 & .158 & .370 & Tidak signifikan \\
\hline Sikap (X3) & .371 & .162 & .027 & Signifikan * \\
\hline Kesetaraan (X4) & .983 & .335 & .006 & Signifikan * \\
\hline
\end{tabular}
berikut: 
Berdasarkan data pada tabel 3 dapat dijelaskan sebagai berikut:

\section{Pengaruh Keterbukaan $\left(\mathrm{X}_{1}\right)$ terhadap Tingkat Efektivitas Komunikasi Antar Pribadi (Y)}

Berdasarkan hasil analisis data diperoleh $p$ value variabel $\mathrm{X}_{1}$ sebesar $0,005 . \mathrm{P}$ value $<\alpha$ atau $0,005<0,05$ maka $\mathrm{H}_{0}$ ditolak dan $\mathrm{H}_{1}$ di terima, artinya keterbukaan secara parsial berpengaruh signifikan terhadap tingkat efektivitas komunikasi antarpribadi pada taraf signifikansi $95 \%(\alpha=0,05)$. Semakin tinggi tingkat keterbukaan petani maka akan semakin tinggi pula tingkat efektivitas komunikasi dirinya dengan petani lainnya dalam hal budidaya padi organik. Semakin terbuka seorang petani kepada petani lain, maka tingkat pemahaman makna dari informasi tersebut akan terserap dengan maksimal sehingga hasilnya informasi yang di anggap baik akan diadopsi oleh petani lain. Gaya komunikasi antarpribadi yang terbuka dan luwes lebih disukai dalam komunikasi antar manusia (De vito,1997).

\section{Pengaruh Empati $\left(\mathbf{X}_{2}\right)$ terhadap Tingkat Efektivitas Komunikasi Antar Pribadi (Y)}

Berdasarkan hasil analisis data diperoleh $p$ valuevariabel $\mathrm{X}_{2}$ sebesar 0,370. pvalue $>\alpha$ atau $0,370>0,05$ maka $\mathrm{H}_{0}$ diterima dan $\mathrm{H}_{1}$ di tolak, artinya empati secara parsial tidak berpengaruh signifikan terhadap tingkat efektivitas komunikasi antarpribadi pada taraf signifikansi $95 \%(\alpha=0,05)$. Tinggi rendahnya tingkat empati seseorang tidak berpengaruh nyata terhadap tingkat efektivitas komunikasi dirinya dengan petani lainnya dalam hal budidaya padi organic.Hal ini tidak sesuai dengan pendapat De vito (1997) yang menyatakan seseorang yang berempati akan memahami posisi yang dirasakan oleh orang lain dan dapat memberikan penlaian terhadap sikap dan perilaku yang dilakukan. Semakin tinggi tingkat empati seseorang akan menentukan keefektifan suatu komunikasi yang terjalin.

\section{Pengaruh Sikap $\left(\mathrm{X}_{3}\right)$ terhadap Tingkat Efektivitas Komunikasi Antar Pribadi (Y)}

Berdasarkan hasil analisis data diperoleh $p$ value variabel $\mathrm{X}_{3}$ sebesar $0,027 . P$ value $<\alpha$ atau $0,027<0,05$ maka $\mathrm{H}_{0}$ ditolak dan $\mathrm{H}_{1}$ di terima, artinya Sikap secara parsial berpengaruh signifikan terhadap tingkat efektivitas komunikasi antarpribadi pada taraf signifikansi $95 \%(\alpha=0,05)$. Semakin baik Sikap seseorang mengenai budidaya padi organik maka akan semakin tinggi pula tingkat efektivitas komunikasi dirinya dengan petani lainnya.Pemikiran petani dan perasaan petani mendukung budidaya padi organik sehingga mereka dengan senang hati mengadopsi di lahan pertaniannya. Sikap positif antar petani mengenai budidaya padi organik mendorong kelancaran dalam proses komunikasi.

\section{Pengaruh Kesetaraan $\left(\mathrm{X}_{4}\right)$ terhadap Tingkat Efektivitas Komunikasi Antar Pribadi(Y)}

Berdasarkan hasil analisis data diperoleh $p$ value variabel $\mathrm{X}_{4}$ sebesar $0,004 . P$ value $<\alpha$ atau $0,004<0,05$ maka $\mathrm{H}_{0}$ ditolak dan $\mathrm{H}_{1}$ di terima, artinya Tingkat kesetaraan secara parsial berpengaruh signifikan terhadap tingkat efektivitas komunikasi antarpribadi pada taraf signifikansi $95 \%(\alpha=0,05)$. Semakin tinggi tingkat kesetaraan petani dengan petani lain maka akan semakin tinggi pula tingkat efektivitas komunikasi yang terjadi dalam hal budidaya padi organik.Hasil ini sesuan dengan pendapat dari Devito (1997) yang menyatakan bahwa komunikasi antarpribadi akan lebih efektif bila suasananya setara.

\section{KESIMPULAN DAN SARAN}

\section{Kesimpulan}

Berdasarkan hasil pembahasan tersebut dapat ditarik kesimpulan sebagai berikut: faktorfaktor yang mempengaruhi komunikasi antar pribadi yaituketerbukaan termasuk dalam kategori cukup terbuka, empati termasuk dalam kategori sedang, sikap termasuk dalam kategori baik, dan kesetaraan dalam kategori sedang,tingkat efektifitas komunikasi antar pribadi petani dalam budidaya padi organik termasuk dalam kategori tinggi, keterbukaan, sikap, empati dan kesetaraan secara bersama-sama berpengaruh signifikan terhadap tingkat efektivitas komunikasi antar pribadi serta keterbukaan, sikap dan kesetaraan secara parsial berpengaruh signfikan terhadap tingkat efektivitas komunikasi antar pribadi namunempati secara parsial tidak berpengaruh signifikan 


\section{Saran}

Berdasarkan hasil penelitian tersebut, saran yang dapat diberikan yaitu perlu ditingkatkan keterbukaan antar petani dengan meningkatkan jumlah kegiatan-kegiatan yang dilakukan Bersama sehingga diharapkan dari kegiatan bersama yang dilakukan akan meningkatkan kedekatan hubungan antar petani menjadi lebih intim dan meningkatkan rasa kepercayaan.Sikap berpengaruh signifikan terhadap tingkat efektivitas komunikasi. Oleh sebab itu peran pemerintah sangat diperlukan dalam hal ini dengan adanya pelatihan-pelatihan dan pendampingan program pertanian organik. Kawasan organik Desa Gentungan memiliki potensi untuk menjadi kawasan wisata organik. Masyarakat mendukung potensi tersebut dan harapannya pemerintah dapat memfasilitasi sehingga dapat dijadikan tambahan pemasukan bagi masarakat.

\section{DAFTAR PUSTAKA}

Andoko, A ., 2010. Budidaya Padi Secara Organik. Cetakan-I. Penebar Swadaya,. Jakarta.

Azwar, S. 1998. Sikap Manusia Teori dan Pengukurannya. Pustaka Pelajar. Yogyakarta.

Devito, J.A. 1997. K o m u n i k a s i Antarmanusia . Penerbit: Professional Book. Jakarta.

Hardjana, A.M. 2003. Komunikasi Intrapersonal dan Interpersonal. Kanisius. Jakarta.

Priyatno. 2012. Mandiri Belajar Analisis Data Dengan SPSS. Mediakom. Yogyakarta.

Ruslan, Rosady. 1998. Manajemen Public Relations dan Media Komunikasi. PT. Raja Grafindo. Jakarta.

Soekartawi, 1988. Prinsip Dasar Komunikasi Pertanian. UI Press. Jakarta.

Suranto Aw. 2011. Komunikasi Interpersonal. Graha Ilmu. Yogyakarta. 